\section{Advancing diversity research in family business}

Family businesses are, by definition, heterogeneous and diverse (e.g., Chua et al., 2012). A search for published articles with the words "diversity" and "family business" in the title indicates that prior literature has focused on diversity in terms of differences among families and their businesses (e.g., Howorth et al., 2010), goals (e.g., Kotlar \& De Massis, 2013), managers' functional backgrounds (Binacci et al., 2016), generation in charge, number of generations or family members employed in the business (e.g., Ling \& Kellermanns, 2010).

Whilst these are certainly indicators of diversity among family businesses, diversity is defined as "the inclusion of different types of people (such as people of different races or cultures) in a group or organization"1 and therefore is a broader construct than what can be found in family business literature. In fact, the Academy of Management 'Gender and Diversity in Organizations Division' (2019) - considers many other forms of diversity, including (but not limited to) gender, race, ethnicity, class, sexual orientation, gender identity, gender expression, nationality, religion, culture, (dis)ability, and age.

With this definition of diversity in mind, one developing area of research that has attracted increasing attention over the last years has focused on gender diversity (see, for reviews of the literature, Campopiano et al., 2017; Martinez Jimenez, 2009). The debate has primarily revolved around the role of women in family business, for example, considering their role in the family as daughters (Akhmedova et al., 2019; Mussolino et al., 2019), their role in succession processes (Ahrens et al., 2015; Overbeke et al., 2013), in top management teams (Chadwick \& Dawson, 2018), and on boards of directors (Amore et al., 2014). Moreover, this stream of literature crosses multiple disciplines, ranging from entrepreneurship (Powell \& Eddleston, 2017; Welsh et al., 2018) over corporate governance (Danes \& Olson, 2003; Rodríguez-Ariza et al., 2017) to organizational behavior (Hedberg \& Danes, 2012).

Despite the important contributions that this line of research has made, gender diversity in family business remains a relatively underdeveloped area of research and family business scholars agree it is increasingly important to further our knowledge of this type of diversity. Furthermore, there is scant literature on other forms of diversity (including race, ethnicity, class, sexual orientation, gender identity, gender expression, nationality, religion, culture, (dis)ability, age, and so on) with few exceptions (e.g., Singal \& Gerde, 2015). Intuitively, we know that diversity is increasingly important and at the forefront of people's consciousness. At the same time, several academic and practitioner studies have indicated a correlation between diversity and financial success (e.g., Hunt et al., 2015).

Therefore, it is an opportune time to deepen our understanding of diversity from different viewpoints (e.g., management, governance, organization), levels of analysis (e.g., individual, group/team, and family/ organization), and theoretical/disciplinary angles (e.g., economics, psychology, anthropology, history, sociology). Finally, we also need to take into account the institutional context in which families and their businesses are embedded and to which they also contribute through their influence (D'Allura, 2019; D'Allura et al., 2019).

This Special Issue on "Advancing Diversity Research in Family Business" aims to fill this gap in the literature under a multidisciplinary approach. Hence, we invite submissions from various disciplines, such as family business, management, gender, diversity, corporate governance, psychology, history, sociology, anthropology, to mention but a few, or combinations thereof.

Contributions can be conceptual (including meta-analyses, critical literature reviews, or "state-of-the-art" articles) and/or empirical (qualitative, quantitative or mixed methods). The special issue aims to critically review and advance theorizations and methodological applications to the study of managing and developing diversity in family businesses, highlighting the relevance of different theories in advancing our knowledge of diversity in this type of organization.

Possible topics/questions include, but are not limited to, the following:

- What are the key antecedents of different types of diversity in family businesses?

- How does diversity influence family business outcomes (e.g., financial and non-financial performance) and behaviors?

- What is the impact of diversity on the strategic path of family businesses and how does this differ from other types of organizations (e. g., non-family businesses)?

- How can family businesses foster an environment that is conducive to greater diversity?

- What policies can be implemented by family businesses in order to favour greater diversity?

- Through what paths do women, minorities, etc. rise to the top of family businesses and do these differ from other types of organizations?

- Does generational stage of the family and/or firm affect diversity in family businesses?

- Do individuals, groups and teams with diverse backgrounds differ in their stewardship attitudes towards family businesses?

- Through what mechanisms do owning families create greater diversity in their businesses and how do outcomes differ across countries and cultures?

- How does the cultural and societal context affect diversity in family business?

\footnotetext{
$\overline{1}$ https://www.merriam-webster.com. 
- How does the institutional context affect diversity in family business?

- How does the intersection between gender and other forms of diversity affect the family business and its sustainability and performance?

- What is the impact of diversity on the well-being and effectiveness at individual, group, and organizational levels of analysis of the family business?

- What are the implications of diversity for leadership of family businesses?

- Should we promote diversity or inclusion in family businesses?

- How do family and nonfamily members experience increasing diversity in the family business?

- What are the main institutional and structural barriers to promoting greater diversity in the family business?

- Which theoretical and methodical lenses could help us to further understand diversity in family business?

- How can gender, diversity and other literatures help us understand this phenomenon better in the context of family business?

- What are adequate measures of diversity and its outcomes and do these differ among family businesses or between family and nonfamily businesses?

\section{Timeline and Submission Information}

All articles for this Special Issue must be submitted online via the Editorial Manager system. The deadline for submissions is December 1, 2020. There will be a rolling review process, such that manuscripts will immediately enter the review process once submitted.

The guest editors will hold several 'meet the guest editors' sessions during major conferences and workshops throughout this year and leading up to the submission due date where authors can obtain feedback on their research ideas and planned submissions to this Special Issue. Please contact the guest editors for further details on these initiatives.

Submissions must follow the manuscript guidelines of JFBS available from this same link (see the 'Guide for Authors' link at the top of the page). Authors should clearly indicate in their cover letter that the manuscript is for the Special Issue "Advancing Diversity Research in Family Business" and choose "SI-Diversity" as article type upon submission.

All articles will be subject to the standard JFBS double-blind review process. For questions regarding this Special Issue, please contact any of the guest editors: Mariasole Bannò (mariasole.banno@unibs.it), Giorgia M. D'Allura (gdallura@unict.it), Alexandra Dawson (alexandra.dawson @concordia.ca), Mariateresa Torchia (mtorchia@inseec.com) or David Audretsch (daudrets@indiana.edu).

\section{About the journal}

The Journal of Family Business Strategy (JFBS) publishes research that contributes new knowledge and understanding to the field of family business. The Journal is interdisciplinary and international in scope and welcomes submissions that address all aspects of how family influences business and business influences family. JFBS publishes quantitative research as well as qualitative work and purely theoretical or conceptual papers. Further details on JFBS can be obtained from http://www.elsev ier.com/locate/jfbs or by contacting the Editor-in-Chief, Torsten Pieper, via tpieper@uncc.edu.

\section{Important dates}

- Manuscripts due by: December 1, 2020

- First round of reviews: February 1, 2021

- First round of revised papers: May 1, 2021

- Second round of reviews: July 1, 2021
- Second round of revised papers: October 1, 2021

- Notification to authors: December 1, 2021

- Final versions due by: January 1, 2022

- Tentative publication of the Special Issue: March 1, 2022

\section{References}

Academy of Management 'Gender and Diversity in Organizations Division'. (2019). Retrieved from http://aom.org/Divisions-and-Interest-Groups/Gender-and-Diversi ty-in-Organizations/Gender-and-Diversity-in-Organizations-Division.aspx.

Ahrens, J. P., Landmann, A., \& Woywode, M. (2015). Gender preferences in the CEO successions of family firms: Family characteristics and human capital of the successor. Journal of Family Business Strategy, 6(2), 86-103.

Akhmedova, A., Cavallotti, R., Marimon, F., \& Campopiano, G. (2019). Daughters' careers in family business: Motivation types and family-specific barriers. Journal of Family Business Strategy. https://doi.org/10.1016/j.jfbs.2019.100307

Amore, M. D., Garofalo, O., \& Minichilli, A. (2014). Gender interactions within the family firm. Management Science, 60(5), 1083-1097.

Binacci, M., Peruffo, E., Oriani, R., \& Minichilli, A. (2016). Are all non-family managers (NFMs) equal? The impact of NFM characteristics and diversity on family firm performance. Corporate Governance: An International Review, 24(6), 569-583.

Campopiano, G., De Massis, A., Rinaldi, F. R., \& Sciascia, S. (2017). Women's involvement in family firms: Progress and challenges for future research. Journal of Family Business Strategy, 8(4), 200-212.

Chadwick, I. C., \& Dawson, A. (2018). Women leaders and firm performance in family businesses: An examination of financial and nonfinancial outcomes. Journal of Family Business Strategy, 9(4), 238-249.

Chua, J. H., Chrisman, J. J., Steier, L. P., \& Rau, S. B. (2012). Sources of heterogeneity in family firms: An introduction. Entrepreneurship: Theory and Practice, 36(6), 1103-1113.

Danes, S. M., \& Olson, P. D. (2003). Women's role involvement in family businesses, business tensions, and business success. Family Business Review, 16(1), 53-68.

D'Allura, G. M. (2019). Family and institutional contexts: An integrated view to advance family business research. In G. M. D'Allura, A. Colli, \& S. Goel (Eds.), Family firms and institutional contexts: Business models, innovation and competitive advantage. Edward Elgar Publishing.

D'Allura, G. M., Colli, A., \& Goel, S. (Eds.). (2019). Family firms and institutional contexts: Business models, innovation and competitive advantage. Edward Elgar Publishing.

Howorth, C., Rose, M., Hamilton, E., \& Westhead, P. (2010). Family firm diversity and development: An introduction. International Small Business Journal, 28(5), 437-451.

Hunt, V., Layton, D., \& Prince, S. (2015). Why diversity matters. McKinsey Insights. available at: https://www.mckinsey.com/business-functions/organization/our-insi ghts/why-diversity-matters.

Kotlar, J., \& De Massis, A. (2013). Goal setting in family firms: Goal diversity, social interactions, and collective commitment to family-centered goals. Entrepreneurship: Theory and Practice, 37(6), 1263-1288.

Ling, Y., \& Kellermanns, F. W. (2010). The effects of family firm specific sources of TMT diversity: The moderating role of information exchange frequency. Journal of Management Studies, 47(2), 322-344.

Martinez Jimenez, R. (2009). Research on women in family firms: Current status and future directions. Family Business Review, 22(1), 53-64.

Mussolino, D., Cicellin, M., Iacono, M. P., Consiglio, S., \& Martinez, M. (2019). Daughters' self-positioning in family business succession: A narrative inquiry. Journal of Family Business Strategy. https://doi.org/10.1016/j.jfbs.2019.01.003

Overbeke, K. K., Bilimoria, D., \& Perelli, S. (2013). The dearth of daughter successors in family businesses: Gendered norms, blindness to possibility, and invisibility. Journal of Family Business Strategy, 4(3), 201-212.

Powell, G. N., \& Eddleston, K. A. (2017). Family involvement in the firm, family-tobusiness support, and entrepreneurial outcomes: An exploration. Journal of Small Business Management, 55(4), 614-631.

Rodríguez-Ariza, L., Cuadrado-Ballesteros, B., Martínez-Ferrero, J., \& GarcíaSánchez, I. M. (2017). The role of female directors in promoting CSR practices: An international comparison between family and non-family businesses. Business Ethics: A European Review, 26(2), 162-174.

Singal, M., \& Gerde, V. W. (2015). Is diversity management related to financial performance in family firms? Family Business Review, 28(3), 243-259.

Welsh, D. H., Kaciak, E., Memili, E., \& Minialai, C. (2018). Business-family interface and the performance of women entrepreneurs: The moderating effect of economic development. International Journal of Emerging Markets, 13(2), 330-349.

Mariasole Bannò $^{\mathrm{a}, *}$, Giorgia M. D'Allura ${ }^{\mathrm{b}}$, Alexandra Dawson ${ }^{\mathrm{c}}$, Mariateresa Torchia ${ }^{\mathrm{d}}$, David Audretsch

${ }^{\mathrm{a}}$ University of Brescia, Italy

${ }^{\mathrm{b}}$ University of Catania, Italy ${ }^{\mathrm{c}}$ Concordia University, Canada

${ }^{\mathrm{d}}$ International University of Monaco, Principality of Monaco ${ }^{\mathrm{e}}$ Indiana University, USA

* Corresponding author. E-mail address: mariasole.banno@unibs.it (M. Bannò). 